\title{
PC有ヒンジ箱桁橋の桁連続化と 制震デバイスの適用による耐震性能照査
}

\author{
杉岡 弘一 1 福島 誉央 $2 \cdot$ 光川 直宏 3 \\ 1正会員 阪神高速道路株式会社 大阪管理部（† 552-0006 大阪市港区石田3-1-25） \\ E-mail:koichi-sugioka@hanshin-exp.co.jp \\ 2正会員 阪神高速道路株式会社大阪管理部（干552-0006 大阪市港区石田3-1-25） \\ E-mail:takahisa-fukushima@hanshin-exp.co.jp \\ 3 正会員 株式会社建設技術研究所 大阪本社（†541-0045 大阪市中央区道修町1-6-7） \\ E-mail:mitukawa@ctie.co.jp
}

PC 3 径間連続有ヒンジ箱桁橋のレベル 2 地震動に対する而震性能向上対策として，中央ヒンジ部での主 桁連続化と端橋脚および中央ヒンジ部での制震デバイスの適用について，その有効性を非線形時刻歴応答 解析の実施を通して検証した。 その結果，制震デバイスの適用としては，せん断パネルダンパーや粘性ダ ンパーのエネルギー吸収による減衰効果により，制震デバイスを適用しない場合に比べて補強部材の規模 や端橋脚部の水平変位を低減できることを確認した。 また，中央ヒンジ部の主林連続化は，耐震性能の向 上に大きく寄与することも確認した。併せて, 中央ヒンジ部と端橋脚部での制震デバイスとの併用により, 補強規模をさらに低減できることを示した.

Key Words : seismic response control devices, continuing beams, seismic retrofit, dynamic analysis, $P C$ hinged rigid frame bridge

\section{1. はじめに}

兵庫県南部地震以降，巨大地震に対する橋梁の安全性 向上を目指して，全国で橋梁の而震補強が実施されてき ている．道路橋の耐震補強法として，一般高架橋の而震 補強に適用される通常の耐力・じん性を向上させる方法 でなく，ダンパーなどのデバイスを用いて積極的に損傷 を制御する制震・免震設計法 ${ }^{1)}$-4) の適用が増加してきて いる.これらの制震・免震設計法によれば，主構造の損 傷の回避や補強範囲の縮小，あるいは補強部材の小規模 化などコスト縮減効果が期待でき，特に，既設長大橋の 而震補強における適用の効果は大きい. 阪神高速道路に おいても制震デバイスとして履歴減衰型のせん断パネル ダンパーの適用を試み，従来の変位制限構造による補強 案との比較設計を通して, 長大橋の構造的特性を考慮し た最適な耐震補強構造を提案している5) - 11). せん断パネ ルダンパーの他にも個々の長大橋の構造特性に適合する 免震・制震技術を積極的に採用し，合理的な長大橋の耐 震補強を実施してきている ${ }^{12)}$ - 16)。これらの阪神高速道路 における耐震補強については文献17) にも示している.
その他の道路や鉄道の高架橋でも，せん断パネルダンパ 一を適用した耐震補強検討 ${ }^{18)-21)}$ が実施され，その有効性 が示されてきている.

PC有ヒンジ箱桁橋は，構造設計の容易さや経済的優 位性から1960年から1980年代にディビダーク工法にて多 く架設されている。しかし，有ヒンジという構造形式か ら，コンクリートの収縮やクリープ等による時間依存変 位が大きく，中央ヒンジでは建設時に予測した変形やた わみを上回ることがある、その結果，中央ヒンジ支承が 摩耗損傷し，車両走行時に振動・騒音が発生するととも に，車両走行性の低下等の機能障害が生じており，主桁 連続化を含む補強対策が実施されている22)-27).

本研究では，まず，対象とするPC 3 径間連続有ヒン シ箱杕橋全体系に対して, 道路橋示方書 $\mathrm{V}$ 而讨震設計編 ${ }^{28)}$ に示されるレベル 2 地震動のタイプ I およびタイプIIを 入力地震動として，橋軸方向の非線形時刻歴応答解析を 実施し，現況構造での而震性能を照査した．次に，PC 3 径間連続有ヒンジ箱桁橋の耐震性能向上対策として, 既設長大橋の耐震補強において適用効果の大きい制震デ バイスを用いた補強案を, 中央ヒンジ部での主桁連続化 
とともに検討した．対象橋梁は橋軸直角方向については 補強が不要との照査結果であったため, 本研究の対象外 とした．補強構造の検討から，PC 3 径間連続有ヒンジ 箱桁橋における制震デバイスの種類や配置の違いによる 而震性能向上効果について, 中央ヒンジ部の主林連続化 による而震性能向上効果とともに考察した.

\section{2. 現況構造の耐震性能照査}

\section{(1) 対象橋梁の概要}

本論文で対象とした橋梁は，阪神高速道路に架橋され た橋長 $166 \mathrm{~m}$ （側径間 48m+中央径間 $70 \mathrm{~m}+$ 側径間 48m) の 3 径間連続 PC 有ヒンジ箱桁橋である. 図-1に橋梁一 般困を示す。

下部構造は，P1，P2，P3 橋脚が門型鉄筋コンクリー 卜橋脚, P4 橋脚が単柱式鉄筋コンクリート橋脚となっ ている. 全ての橋脚は兵庫県南部地震後, 鋼板巻立て工 法によって既に補強されている. 支承条件については, 中間支点 P2, P3 橋脚では上下部剛結構造であり，端橋 脚 P1，P4 橋脚では橋軸方向に対して鋼製の可動支承が, 中央ヒンジ部は鋼製のゲレンク沓が採用されている. な お，端橋脚 $\mathrm{P} 1, \mathrm{P} 4$ 橋脚の橋軸直角方向は固定である.
しゅん工は 1964 年（昭和 39 年）であり，而震設計は レベル 1 地震に対して震度法により行われている．地盤 種別は II 種地盤であり，建設時の設計水平震度は 0.25 である。

\section{（2） 入力地震波}

解析に用いる地震波は，道路橋示方書 $\mathrm{V}$ 而震設計編 ${ }^{28)}$ に示される II 種地盤の標準加速度波形を用いた．表-1に 入力地震波を示す.

\begin{tabular}{|c|c|c|}
\hline 地震名 & 記録場所及び成分 & 呼び名 \\
\hline $\begin{array}{l}\text { 平成15年 } \\
\text { 十勝沖地震 }\end{array}$ & $\begin{array}{l}\text { 直別観測点地盤上 } \\
\text { [EW成分 }]\end{array}$ & I - II -1 \\
\hline \multirow{2}{*}{$\begin{array}{l}\text { 平成23年 } \\
\text { 東北地方 } \\
\text { 太平洋沖地震 }\end{array}$} & $\begin{array}{l}\text { 仙台河川国道事務所構内地盤上 } \\
\text { [EW成分 }]\end{array}$ & I $-\Pi$ - -2 \\
\hline & $\begin{array}{l}\text { 阿武隈大堰管理所構内地盤上 } \\
\text { [NS成分] }\end{array}$ & I - II -3 \\
\hline \multirow{3}{*}{$\begin{array}{l}\text { 平成7年 } \\
\text { 兵庫県南部 } \\
\text { 地震 }\end{array}$} & $\begin{array}{l}\text { JR西日本鷹取駅構内地盤上 } \\
\text { [NS成分 }]\end{array}$ & ПI-П -1 \\
\hline & $\begin{array}{l}\text { JR西日本鷹取駅構内地盤上 } \\
\text { [EW成分 }]\end{array}$ & II - ПI-2 \\
\hline & $\begin{array}{l}\text { 大阪ガス蕞合供給所構内地盤上 } \\
\text { [N27W成分 }]\end{array}$ & II - II -3 \\
\hline
\end{tabular}
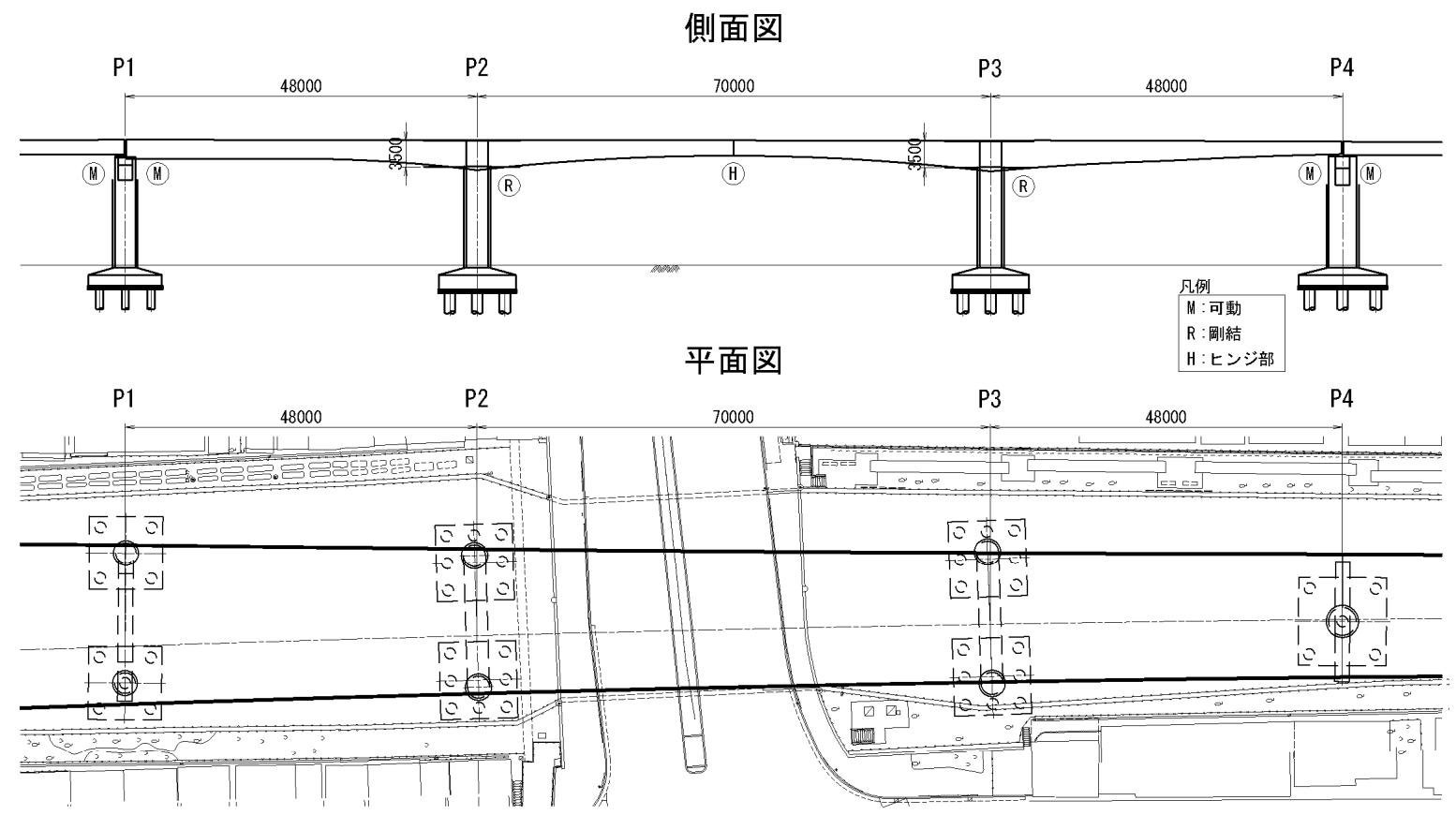

断面図

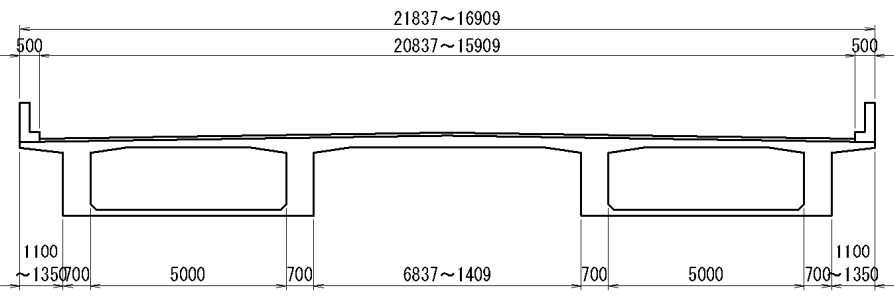

図-1 対象橋梁一般図 (単位 $m$ m) 


\section{(3) 解析モデル}

対象橋梁の耐震性能を照査寸るために，3 次元骨組モ デルにより非線形時刻歴応答解析を実施した．解析に用 いたソフトはTDAPIII（Ver3.05_01）である. 解析条件を 表-2に，解析モデルを図-2に示す.

各部材のモデル化にあたり，上部構造や橋脚について は，降伏が予想されることから非線形部材としM- $\phi$ 要 素によりモデル化 ${ }^{29)}$ - 30) した。 上部構造の非線形特性を図 -3に，下部構造の非線形特性を図-4に示寸.

鉄筋コンクリート橋脚においては，梁部を剛部材，柱 部を非線形はり要素でモデル化した. 鉄筋コンクリート 橋脚柱部においてはTakedaモデルを用い，その除荷時剛 性低下指数 $\alpha$ は 0.4 とした。 また，基礎は線形バネとし て基礎中心に集約して配置した.

表-2 解析条件

\begin{tabular}{|c|c|c|}
\hline \multicolumn{2}{|c|}{ 解析手法 } & 時刻歴応答解析 \\
\hline \multicolumn{2}{|c|}{ 固有值解析 } & サブスペース法 \\
\hline \multicolumn{2}{|c|}{ 積分手法 } & Newmark $-\beta$ 法 $(\beta=0.25)$ \\
\hline \multicolumn{2}{|c|}{ 減衰の評価方法 } & Rayleigh減衰 \\
\hline \multicolumn{2}{|c|}{ 積分時間間隔 } & 0.002 秒 \\
\hline \multirow{4}{*}{$\begin{array}{l}\text { 要素 } \\
\text { 条件 }\end{array}$} & 上部構造 & 非線形はり要素 \\
\hline & 下部構造（梁） & 岡部材 \\
\hline & 下部構造（橋脚） & 非線形はり要素 \\
\hline & 支承 & 線形バネ要素 \\
\hline \multicolumn{2}{|c|}{ 上部工部材の復元モデル } & トリリニア型 \\
\hline \multicolumn{2}{|c|}{ 橋脚部材の復元モデル } & トリリニア型（Takedaモデル） \\
\hline \multicolumn{2}{|c|}{ 要素別減衰定数 } & $\begin{array}{l}\text { 上部構造（PC桁） : } 3 \% \\
\mathrm{RC} \text { 橋脚 : } 2 \% \\
\text { 基礎 : } 20 \%\end{array}$ \\
\hline
\end{tabular}

\section{（4）固有振動特性}

固有值解析における代表的な固有振動モードを図-5 に示す．橋軸方向 1 次モードは，固有周期約 0.84 秒，有 効質量比約 60\%であり, 中間橋脚部の並進に伴い上部構 造が鉛直にたわむ振動形状を示した．橋軸方向 2 次モー ドは，固有周期約 0.06 秒，有効質量比約 $1 \%$ となり，上 部構造の変形は小さく端橋脚が大きく変形する振動形状 を示した. 橋軸方向 1 次モードの固有周期に相当する最 大加速度応答スペクトルは, 約 1750gal であった.

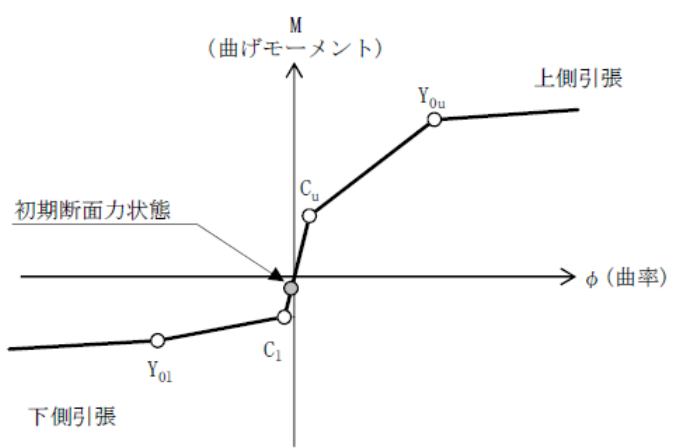

図-3上部構造の非線形モデル

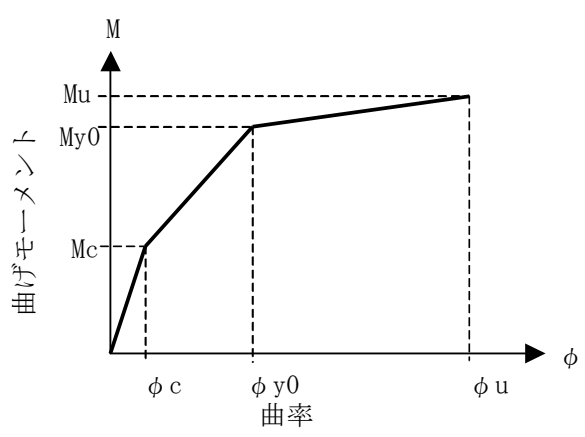

図-4 RC 橋脚の非線形モデル

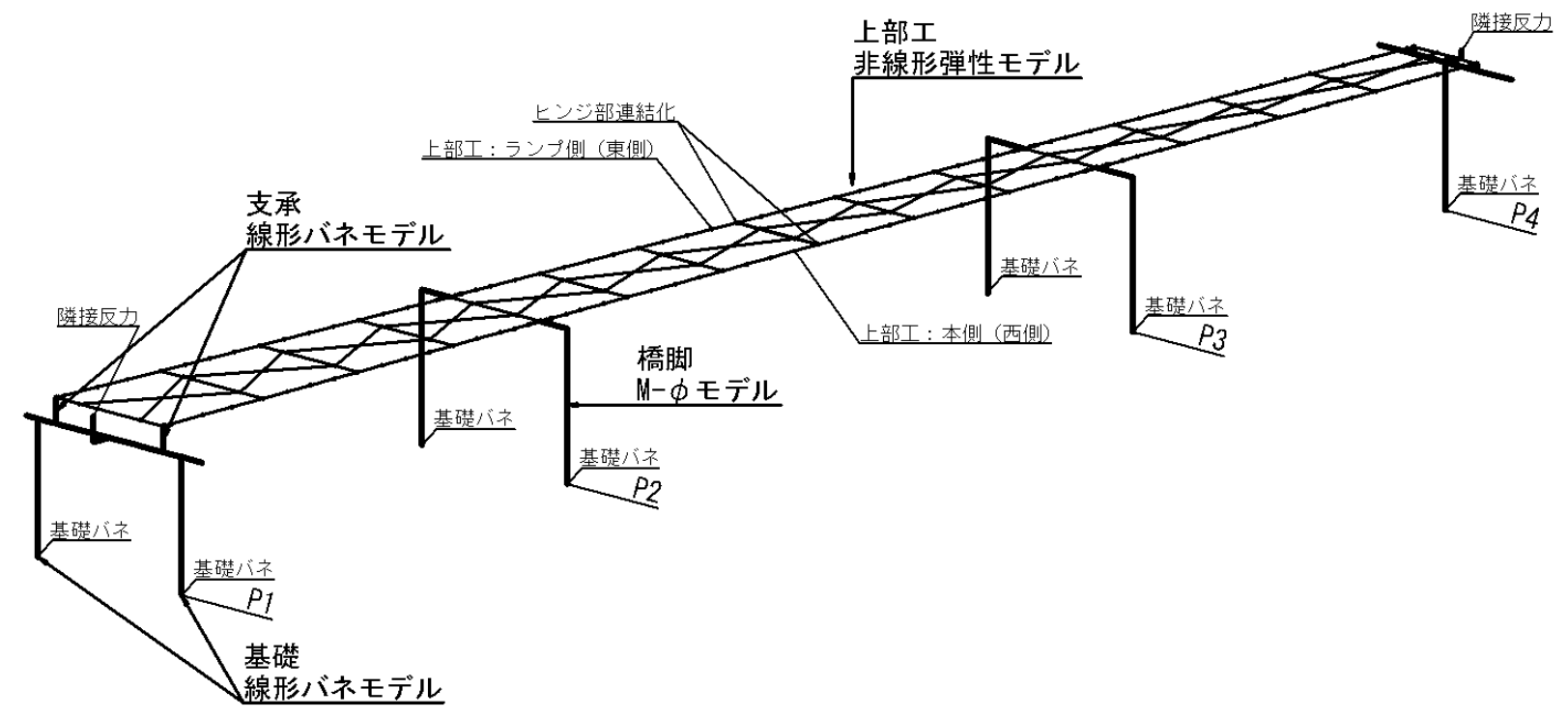

図-2 解析モデル 


\section{(5) 耐震性能照査}

レベル 2 地震時に対象橋梁各部に求める限界状態を表 -3に示す．上部構造はPC部材であるため, 弾性範囲内と し, 補強済みとなる橋脚は補強後の許容值を満足する範 囲に留めることとした.

橋軸方向加振時の非線形時刻歴応答解析の結果から, 各部材毎に応答值を許容值で除した比率を図-6に示す. ここで, 応答值を許容值で除した比率が 1 を下回る部材 は安全であることを示しており, 着色した凡例に応じて 許容值に対する超過度を示している.

鋼板巻立てによる補強が行われている橋脚においては, 全ての部材で許容值に収まっていることを確認した．上 部構造においては，曲げ，せん断ともに中央ヒンジ付近 に超過度の高い部材が集中しており, 現況の有ヒンジ構 造による支間中央部の断面性能が他の部位に比較して小 さいことに起因している.

なお，橋軸直角方向については，上部構造，下部構造 の全部材において応答值が許容值を下回ることを確認し 補強が不要であったため, 本研究の対象外としている.

$\mathrm{T}=0.84 \mathrm{sec}$

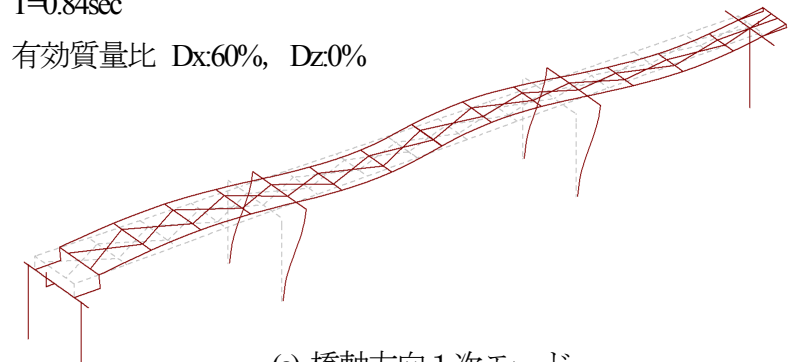

(a) 橋軸方向 1 次モード

$\mathrm{T}=0.06 \mathrm{sec}$

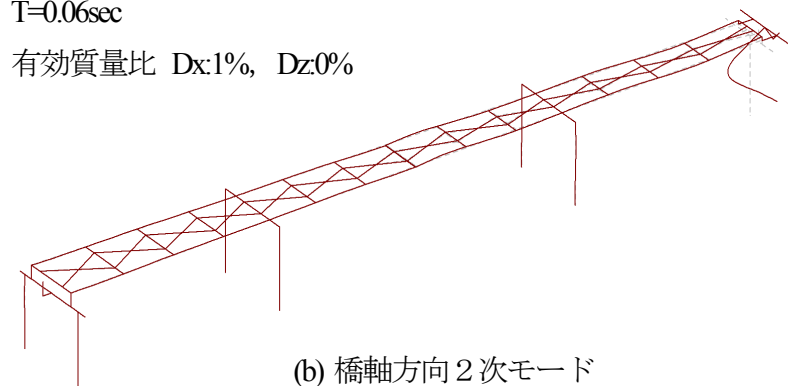

図-5 固有振動モード図

表-3＼cjkstart橋梁各部に求める限界状態（レベル2 地震時）

\begin{tabular}{|l|l|l|}
\hline & \multicolumn{2}{|c|}{ 各部の限界状態 } \\
\hline 上部構造 & 力学的挙動が弾性域を超えない \\
\hline \multirow{2}{*}{ 支承部 } & 応力 & 力学的挙動が弾性域を超えない \\
\cline { 2 - 3 } & 移動 & 脱落や隣接桁との衝突を生じない \\
\hline 下部構造 & 修復を容易に行い得る \\
\hline 基礎 & \multicolumn{2}{|l|}{ 副次的な塑性化にとどまる } \\
\hline
\end{tabular}

端橋脚の水平変位については，主桁の遊間を許容值と すると，表-4に示すとおり，許容值を大きく越える応答 変位を確認した.

\section{3. 耐震性能向上対策}

\section{（1）耐震性能向上対策案の選定}

現況構造に対する而震性能照査の結果，橋軸方向加振 時において，上部構造の一部に曲げおよびせん断照査で 許容值を超過することが確認されている，ただし，応答 值が許容值を超過する部材は中央径間付近に集中してい ることから，主枌の変形を抑制する耐震性能向上対策を 検討することとした，その対策としては，エネルギー吸 収による減衰効果と主林の変位制御を同時に満たす免 震・制震技術の採用が有効と考えた.

ここで，免震・制震デバイスの設置箇所として，端橋 脚と中央ヒンジ部の2箇所に着目し，各々の箇所におけ る免震・制震対策案を表-5に抽出した，併せて，耐震性 能解析ケースを表-6に示す.

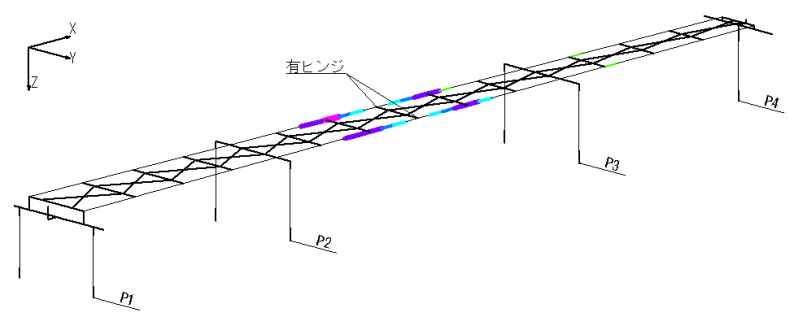

(a) 曲げ

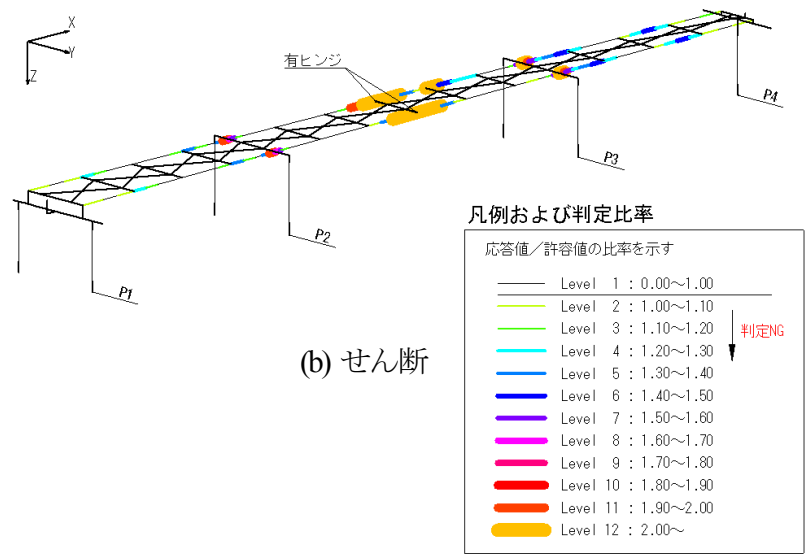

図-6 解析結果 (現況構造)

表-4 端橋脚における応答変位

\begin{tabular}{|c|c|c|}
\hline 橋脚名 & 最大変位量 $(\mathrm{mm})$ & 許容值 $\delta \mathrm{a}(\mathrm{mm})$ \\
\hline $\mathrm{P} 1$ & $0.297(3.71 \delta \mathrm{a})$ & 0.080 \\
\hline $\mathrm{P} 4$ & $0.270(5.40 \delta \mathrm{a})$ & 0.050 \\
\hline
\end{tabular}


表-5 免震・制震対策案

\begin{tabular}{|c|c|c|c|}
\hline \multicolumn{3}{|r|}{ 対策案 } & 期待する改善効果 \\
\hline \multirow{4}{*}{ 端橋脚部 } & 第 1 案 & 粘性ダンパー & $\begin{array}{l}\text { 端橋脚に粘性ダンパーを設置することで，減衰を期待する } \\
\text { 案. 端橋脚に作用力が分担されるため，補強済み橋脚が許容 } \\
\text { 值を超過する可能性がある. }\end{array}$ \\
\hline & 第 2 案 & 免震支承 & $\begin{array}{l}\text { 端橋脚を免震支承に取替えることにより，減衰を期待する } \\
\text { 案. 第 } 1 \text { 案と同じ減衰効果は期待できるが，鉿直，回転機能 } \\
\text { や構造高さによる制約が多い. }\end{array}$ \\
\hline & 第3案 & $\begin{array}{l}\text { 多点固定 } \\
\text { (変位制限構造) }\end{array}$ & $\begin{array}{l}\text { 多点固定化により, 橋梁全体系でバランスよく而震化する } \\
\text { 案. 橋脚は補強済みであるため, 上部構造の応答を軽減する } \\
\text { には端橋脚の再補強が必要な場合がある. }\end{array}$ \\
\hline & 第 4案 & せん断パネルダンパー & $\begin{array}{l}\text { 端橋脚にせん断パネルダンパーを設置し，減衰を期待する } \\
\text { 案. 端橋脚の桁遊間が狭い場合は，減衰を期待できる変位量 } \\
\text { を確保することが困難となる. }\end{array}$ \\
\hline \multirow{2}{*}{$\begin{array}{l}\text { 中央 } \\
\text { ヒンジ部 }\end{array}$} & 第 1 案 & せん断パネルダンパー & $\begin{array}{l}\text { 中央ヒンジ部の鈆直方向にせん断パネルダンパーを設置する } \\
\text { ために, 連結部構造を鋼部材によるハイブリッド構造に改良 } \\
\text { する案. }\end{array}$ \\
\hline & 第2案 & 桁連結 & $\begin{array}{l}\text { 有ヒンジ部を桁連結化し連続構造とすることで, 構造系を変 } \\
\text { 更する案. }\end{array}$ \\
\hline
\end{tabular}

表-6 而震性能解析ケース

\begin{tabular}{|l|c|c|}
\hline \multirow{2}{*}{$\begin{array}{c}\text { 解析 } \\
\text { ケース }\end{array}$} & \multicolumn{2}{|c|}{ 而震性能向上対策 } \\
\cline { 2 - 3 } & 端橋脚部 & 中央ヒンジ部 \\
\hline 現況構造 & - & - \\
\hline Case 1-1 & 粘性ダンパー & - \\
\hline Case 1-2※1) & せん断パネルダンパー & - \\
\hline Case2-1 ※2) & - & せん断パネルダンパー \\
\hline Case2-2 & - & 桁連結 \\
\hline Case3-1※3) & せん断パネルダンパー & せん断パネルダンパー \\
\hline Case3-2※3) & せん断パネルダンパー & 桁連結 \\
\hline
\end{tabular}

※1：せん断パネルダンパーは 3 タイプ設定（表-7） ※2 : せん断パネルダンパーは 3 タイプ設定（表-10） $※ 3$ : 端橋脚を橋台とした解析ケースも設定（表-13）

端橋脚においては，可動支承部との相性を勘案しつつ， 4案の対策案を抽出したが，支承の移動可能範囲，デバ イスの設置スペース，期待される減衰効果を総合的に判 断し，本論文では，粘性ダンパー案およびせん断パネル ダンパー案の検証結果を示している.

中央ヒンジ部においては，有ヒンジ部を改良し設計荷 重時においても構造成立性のあるものでなければならな い. よって, 有ヒンジ部を鋼構造とのハイブリッド構造 に改良し，せん断パネルダンパーを兼用した構造を新た に提案し検証した.さらに，長期たわみによる中央ヒン ジ部の垂れ下がり対策として桁連結化の可能性があるこ とから, 主林連結化も研究対象とした.

併せて, 端橋脚部と中央ヒンジ部に制震デバイスを併 用した場合の適用効果を検証した.

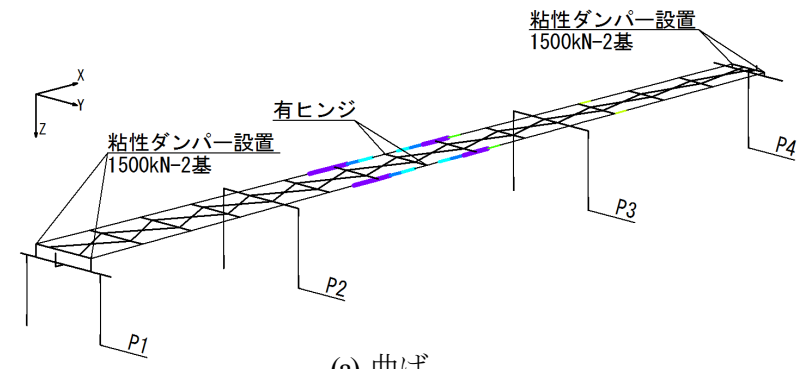

(a) 曲げ

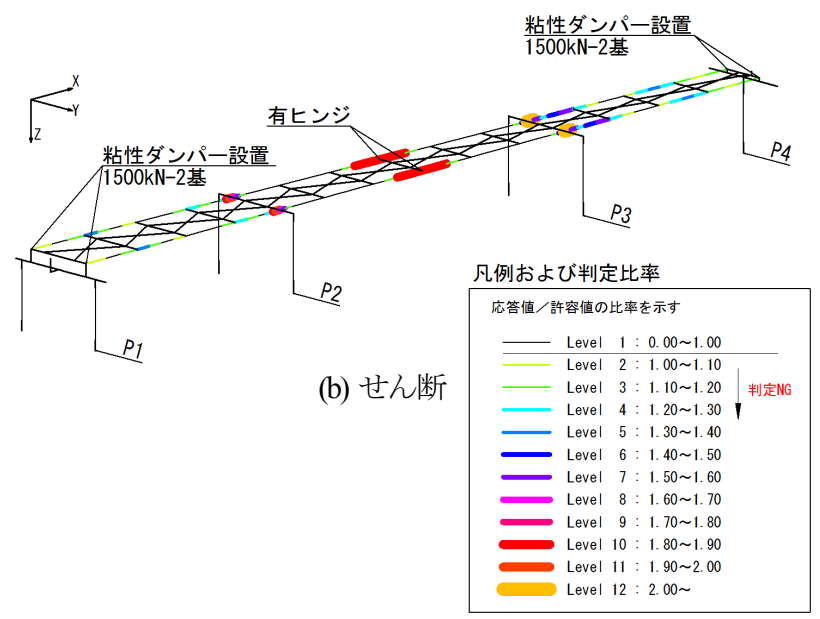

図-7 解析結果 (Case 1-1)

\section{(2) 端橋脚部における制震デバイスの効果}

端橋脚部における制震デバイスの適用効果を検証する ために，端橋脚部に粘性ダンパー（1500kN ×2 基）を設 置した。 なお，対象橋梁の林遊間は起点側で $80 \mathrm{~mm}$ ，終 点側で50mmであることから，水平変位の抑制を目的と して，大容量の粘性ダンパーを選定した。また，変位が 小さくても所定の性能が発揮できるように，速度依存性 の小さい粘性ダンパーを選定した。図-7に橋軸方向加振 
時の非線形時刻歴応答解析の結果から，各部材毎に応答 值を許容值で除した比率を示す.

曲げ・せん断照査に対しては応答に大きな変化はなく, 中央ヒンジ部付近に若干の改善効果が見られるものの許 容值に対しては大きく超過する結果であった.

端橋脚部に設置した制震ダンパーの応答履歴曲線を図 -8に示す。なお，図-8(a) の右側および図-8(b) の左側が 支間中央側を示している，粘性ダンパーの挙動は支間中 央側に寄っており，エネルギー吸収を図る大きなループ を描いていないことが確認された.

P1およびP4橋脚に設置された粘性ダンパーと橋脚の時 刻歴を図-9に示す。図-8に示す粘性ダンパーの応答履歴 曲線でも確認されたとおり，粘性ダンパーの応答は支間 中央側に推移しているものの，橋脚の応答は正負対称と なっている. これは, 本論文の対象橋梁であるPC有ヒン

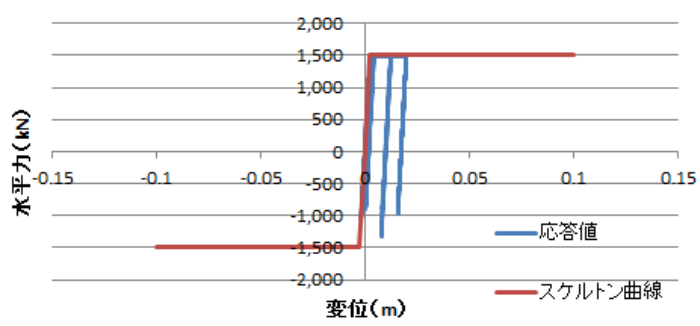

(a) P1橋脚 $\cdot$ G1桁

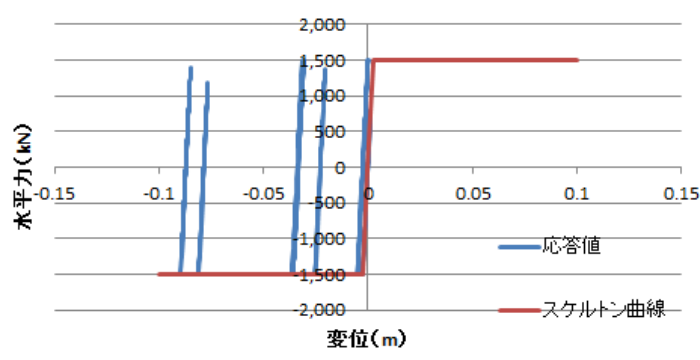

(b) P4橋脚 $\cdot$ G1 枌

図-8＼cjkstart粘性ダンパーの履歴曲線（Case 1-1）

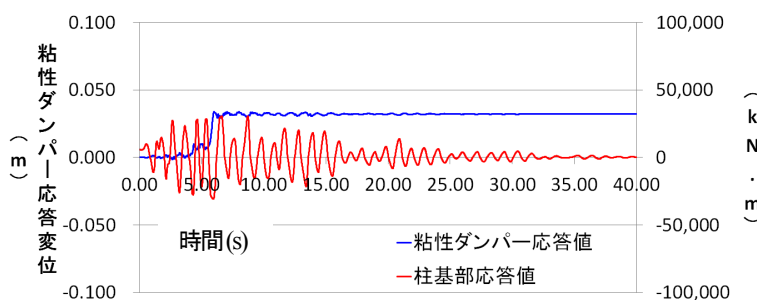

(a) P1橋脚

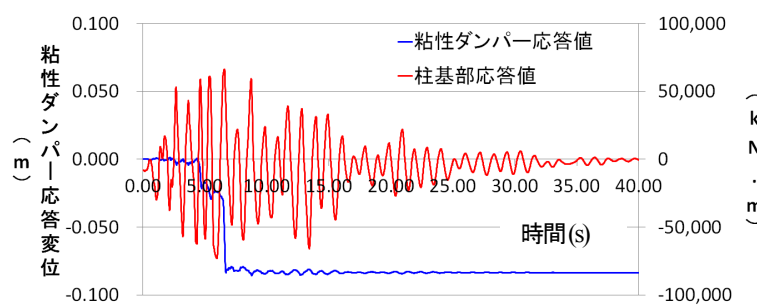

(b) P4橋脚

図-9 粘性ダンパーと柱基部の挙動（Case 1-1）
ンジ箱桁橋の端橋脚における支点反力の方が，隣接橋梁 の端支点反力よりも大きいことから，端橋脚には初期断 面力として支間中央側に偏心曲げが生じているためと考 えられる. そのため, 粘性ダンパーよりも橋脚の塑性化 が支配的となっており，粘性ダンパーが片効きしている ためと考えられる. また，門型鉄筋コンクリート橋脚で あるP1橋脚より，単柱式鉄筋コンクリート橋脚であるP4 橋脚の方が岡性が低いため, 橋脚の応答が大きく，粘性 ダンパーの残留変位も大きいことが確認された.

次に，端橋脚部における制震デバイスの適用効果を検 証するために，せん断パネルダンパーを設置した.

端橋脚部においては，設計反力を $600 \mathrm{kN}, 800 \mathrm{kN}, 1000 \mathrm{kN}$ と変化させた 3 ケースを設定し，それぞれ最適となった せん断パネルダンパーの構造諸元を表-7に示す.

せん断パネルダンパーの設計反力が小さいCase 1-2-1で は，せん断パネルダンパーの許容変位および降伏耐力を 大きく超過していた．また，設計反力が大きいCase 1-2-3 では，せん断パネルダンパーによるエネルギー吸収が小 さく，応答值の低減効果が見られなかった。一方，せん 断パネルダンパーの設計反力を $800 \mathrm{kN}$ と規模にした Case 1-2-2では，せん断パネルダンパーの許容值を満足し つつ，エネルギー吸収が期待できることを確認した.

また，端橋脚部に設置したせん断パネルダンパーの規 格の違いによる橋脚基部に発生するせん断を比較した.

表-8に示すとおり，せん断パネルダンパーの規格の違い は，橋脚基部に発生するせん断に大きくは影響しないこ とを確認した.

表-7 せん断パネルの諸元（端橋脚部）

\begin{tabular}{|c|c|c|c|}
\hline 解析ケース & Case 1-2-1 & Case 1-2-2 & Case 1-2-3 \\
\hline 設計反力 $(\mathrm{kN})$ & 600 & 800 & 1000 \\
\hline 幅B $(\mathrm{mm})$ & 450 & 450 & 500 \\
\hline 高さH $(\mathrm{mm})$ & 500 & 500 & 550 \\
\hline 降伏耐力Py $(\mathrm{kN})$ & 727 & 909 & 1143 \\
\hline 許容耐力 $\mathrm{H}_{\mathrm{Da}}(\mathrm{kN})$ & 642 & 802 & 1009 \\
\hline 許容変位 $\delta_{\mathrm{Da}}(\mathrm{mm})$ & 45 & 45 & 50 \\
\hline
\end{tabular}

表-8 せん断パネルの違いによる柱基部のせん断の比較

\begin{tabular}{|c|c|c|c|}
\hline \multirow{2}{*}{ 橋脚名 解析ケース } & \multicolumn{3}{|c|}{ せん断 $(\mathrm{kN})$} \\
\cline { 2 - 4 } & Case 1-2-1 & Case 1-2-2 & Case 1-2-3 \\
\hline P1 (左柱) & 3,048 & 3,058 & 3,071 \\
\hline P1 (右柱) & 3,059 & 3,081 & 3,095 \\
\hline P2 (左柱) & 11,631 & 11,631 & 11,632 \\
\hline P2 (右柱) & 11,630 & 11,630 & 11,630 \\
\hline P3 (左柱) & 11,828 & 11,827 & 11,816 \\
\hline P3 (右柱) & 11,829 & 11,817 & 11,816 \\
\hline P4 & 6,256 & 6,283 & 6,273 \\
\hline
\end{tabular}


橋梁全体系での応答として，せん断パネルダンパーの 規格として最適な解析Case 1-2-2における橋軸方向加振時 の非線形時刻歴応答解析の結果から，各部材毎に応答值 を許容值で除した比率を図-10に示す。曲げ・せん断照 査に対しては応答に大きな変化はなく, 中央ヒンジ部付 近に若干の改善効果が見られるものの許容值に対しては 大きく超過する結果であった.

端橋脚部に設置したせん断パネルダンパーの応答履歴 曲線を図-11に示す。なお，図-11(a) の右側および図一 11 (b) の左側が支間中央側を示している．粘性ダンパー の挙動と同様に，せん断パネルダンパーの挙動は支間中 央側に寄っており，エネルギ一吸収を図る大きなループ を描いていなことが確認された.

P1およびP4橋脚に設置されたせん断パネルダンパーと 橋脚の時刻歴を図-12に示す。前述した粘性ダンパーお よび柱基部の挙動と同じ傾向にあるものの，せん断パネ ルダンパーの残留変位は小さかった。これは，粘性ダン パーよりもせん断パネルダンパーの方が初期剛性の勾配 が大きく, 変位抑制に寄与しているためと考えられる.

また，端橋脚部の水平変位についても，表-9に示すと おり，制震デバイスの設置効果により，大きな水平変位

（相対変位）の低減を確認した. 現況構造では, 端橋脚 P4の支承変位は最大 $270 \mathrm{~mm}$ であるが，粘性ダンパーを設 置することにより最大変位は $83 \mathrm{~mm}$ ，せん断パネルダンパ 一を設置することにより最大変位は $32 \mathrm{~mm}$ となり，約 $88 \%$ 低減することが確認された.

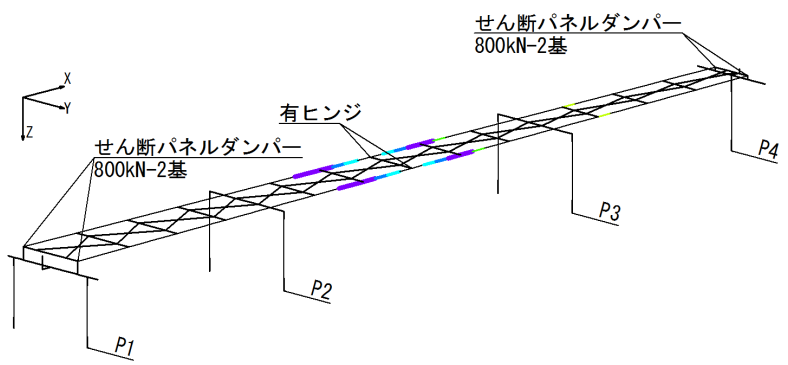

(a) 曲げ

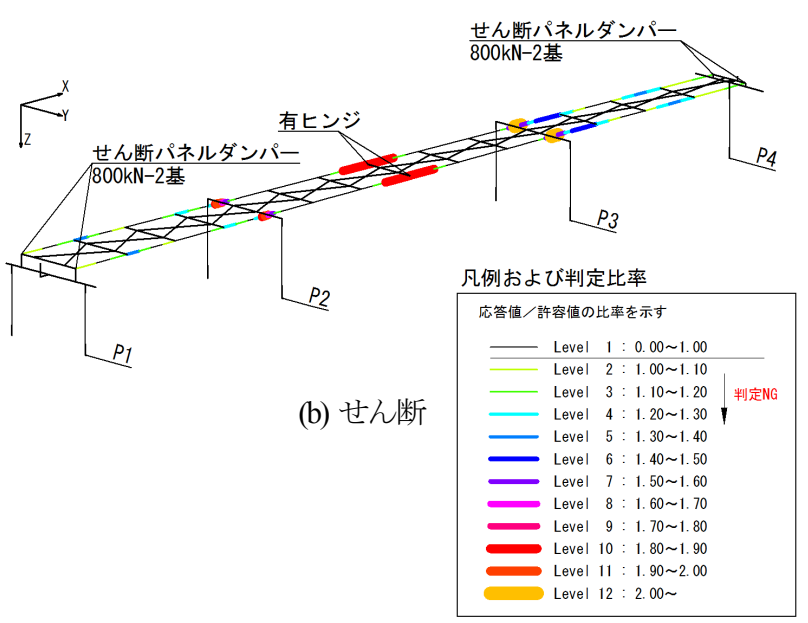

図-10 解析結果 (Case 1-2-2)
以上より，端支点部の制震デバイスとしては，粘性ダ ンパーよりもせん断パネルダンパーの方が優位であるこ とが確認された.

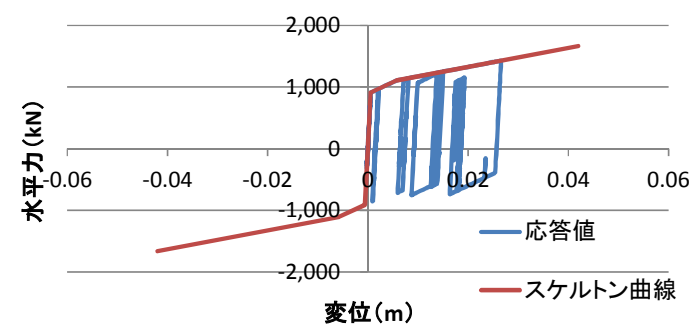

(a) P1 橋脚· G1 桁

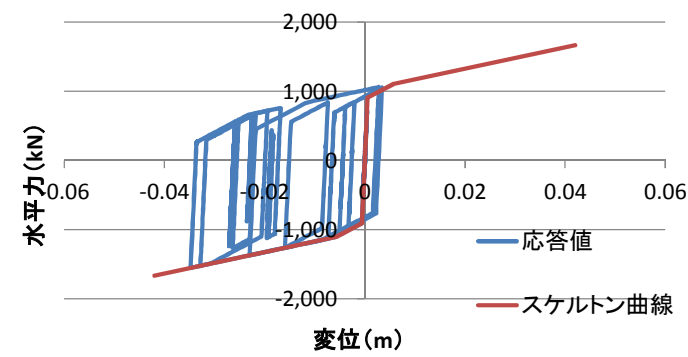

(b) P4橋脚・ G1栴

図-11 せん断パネルダンパー履歴曲線（Case 1-2-2）

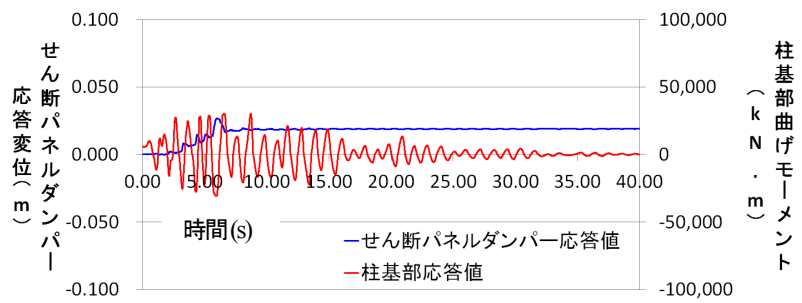

(a) P1橋脚

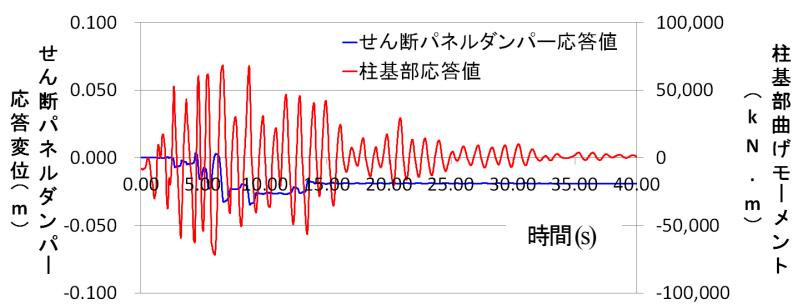

(b) P4橋脚

図-12 せん断パネルダンパーと柱基部の挙動（Case 1-2-2）

表-9 端橋脚部における応答変位の変化

\begin{tabular}{|c|c|l|}
\hline 橋脚名 & 解析ケース & \multicolumn{1}{|c|}{ 最大変位量 $(\mathrm{mm})$} \\
\hline \multirow{3}{*}{ P1 } & 現況構造 & $0.297(3.71 \delta a)$ \\
\cline { 2 - 3 } & Case 1-1 & $0.022(0.28 \delta \mathrm{a})[93 \%$ 減少 $]$ \\
\cline { 2 - 3 } & Case 1-2 & $0.025(0.31 \delta \mathrm{a})[92 \%$ 減少 $]$ \\
\hline \multirow{3}{*}{ P4 } & 現況構造 & $0.270(5.40 \delta a)$ \\
\cline { 2 - 3 } & Case 1-1 & $0.083(1.66 \delta \mathrm{a})[69 \%$ 減少 $]$ \\
\cline { 2 - 3 } & Case 1-2 & $0.032(0.64 \delta \mathrm{a})[88 \%$ 減少 $]$ \\
\hline
\end{tabular}




\section{(3) 中央ヒンジ部における制震デバイスの効果}

中央ヒンジ部における制震デバイスの適用効果を検証 寸るために，中央ヒンジ部の鉛直方向に対して，せん断 パネルダンパーを設置した。 構造概要を図-13に示す. 死荷重の低減，施工性等を考慮して，中央ヒンジ部に鋼 部材を用いてハイブリッド構造とする改造構造を提案し た.

中央ヒンジ部のせん断パネルダンパーにおいては，設 計反力を $200 \mathrm{kN}, 800 \mathrm{kN}, 1200 \mathrm{kN}$ と変化させた 3 ケースを設 定し，それぞれ最適となったせん断パネルダンパーの構 造諸元を表-10に示寸．また，せん断パネルダンパーの 応答履歴を図-14に示す。

せん断パネルダンパーの設計反力が小さいCase 2-1-1で は，せん断パネルダンパーの許容変位および降伏耐力を 大きく超過しており，鉛直方向に対寸る拘束効果もなか った．また，設計反力が大きいCase 2-1-3では，せん断パ ネルダンパーによるエネルギー吸収が小さく, 応答值の 低減効果が見られなかった。一方，せん断パネルダンパ 一の設計反力を $800 \mathrm{kN}$ 中規模にしたCase 2-1-2では，せ ん断パネルダンパーの許容值を満足しつつ, エネルギー 吸収が期待できることを確認した.

また，せん断パネルダンパーの規格の違いによる橋脚 基部に発生するせん断を比較した．表-11に示すとおり， せん断パネルダンパーの規格の違いは，橋脚基部に発生 するせん断に大きく影響しないことを確認した.
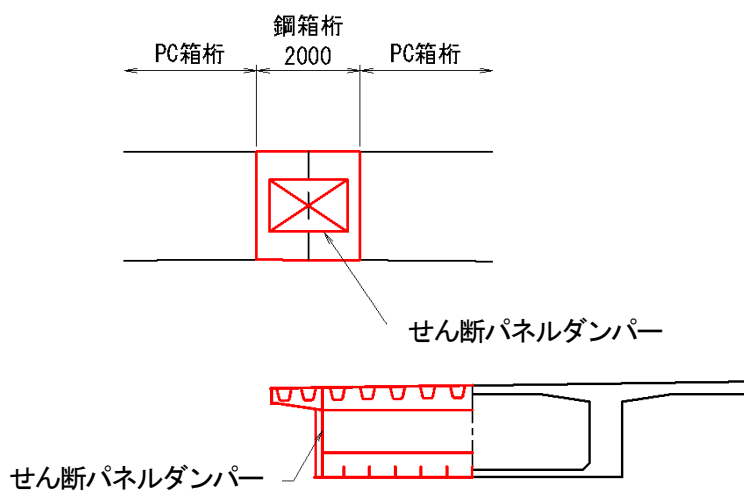

図-13 中央ヒンジ部の改造概要図

表-10 せん断パネルの諸元（中央ヒンジ部）

\begin{tabular}{|c|c|c|c|}
\hline 解析ケース & Case2-1-1 & Case 2-1-2 & Case 2-1-3 \\
\hline 設計反力 $(\mathrm{kN})$ & 200 & 800 & 1200 \\
\hline 幅B $(\mathrm{mm})$ & 300 & 450 & 500 \\
\hline 高さH $(\mathrm{mm})$ & 300 & 500 & 550 \\
\hline 降伏耐力Py $(\mathrm{kN})$ & 234 & 909 & 1364 \\
\hline 許容耐力 $\mathrm{H}_{\mathrm{Da}}(\mathrm{kN})$ & 206 & 802 & 1203 \\
\hline 許容変位 $\delta_{\mathrm{Da}}(\mathrm{mm})$ & 30 & 45 & 50 \\
\hline
\end{tabular}

橋梁全体系での応答として，せん断パネルダンパーの 規格として最適な解析Case 2-1-2における橋軸方向加振時 の非線形時刻歴応答解析の結果功，各部材毎に応答值 を許容值で除した比率を図-15に示す，曲げ・せん断に 対しては，応答值に大きな変化はなく, 中央ヒンジ部付 近に若干の応答低減効果が見られるものの，橋梁全体系 での応答低減効果は軽微であり, 端橋脚部に制震デバイ スを設置した図-7および図-10と同様に，許容值に対し て大きく超過していた.

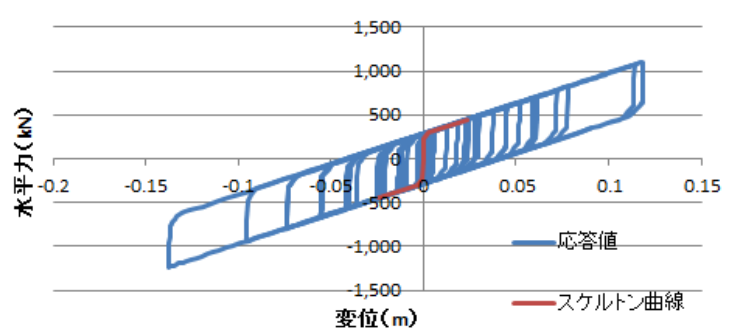

(a) Case2-1-1

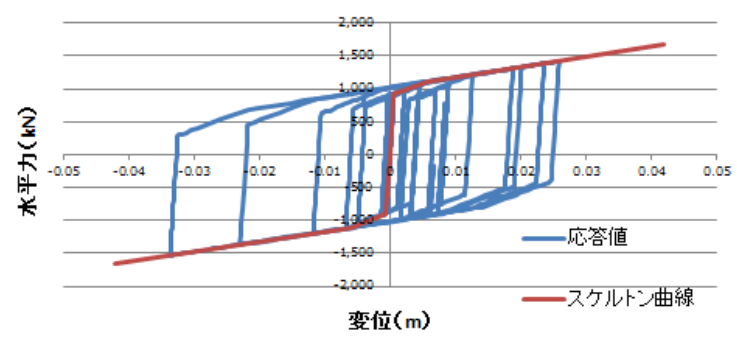

(b) Case2-1-2

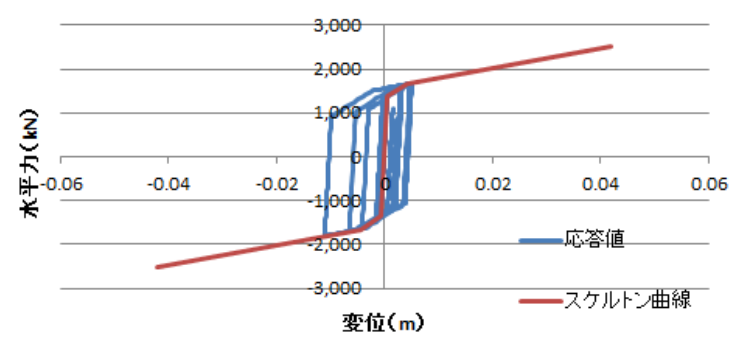

(c) Case2-1-3

図-14 せん断パネルダンパー履歴曲線

表-11 せん断パネルの違いによる柱基部のせん断の比較

\begin{tabular}{|c|c|c|c|}
\hline \multirow{2}{*}{ 橋脚名 解析ケース } & \multicolumn{3}{|c|}{ せん断 $(\mathrm{kN})$} \\
\cline { 2 - 4 } & Case2-1-1 & Case2-1-2 & Case2-1-3 \\
\hline P1 (左柱) & 2,566 & 2,589 & 2,588 \\
\hline P1 (右柱) & 2,583 & 2,608 & 2,608 \\
\hline P2 (左柱) & 12,418 & 12,522 & 12,528 \\
\hline P2 (右柱) & 12,417 & 12,521 & 12,528 \\
\hline P3 (左柱) & 12,277 & 12,403 & 12,443 \\
\hline P3 (右柱) & 12,277 & 12,403 & 12,443 \\
\hline P4 & 7,110 & 7,109 & 7,114 \\
\hline
\end{tabular}




\section{(4) 主桁連結化の効果}

而震性能向上対策として主桁を連結化するために，中 央ヒンジ部をピン構造から剛結構造に構造系を変更した なお，桁連結後の部材特性は常時に対する補強で決定さ れる外ケーブル補強を考慮したものとした．橋軸方向加 振時の非線形時刻歴応答解析の結果から，各部材毎に応 答值を許容值で除した比率を図-16に示す.

曲げ・せん断に対しては，橋梁全体で応答值の低減が 確認され，許容值を超過する範囲は大幅に減少した。 こ れは，現況構造において中央径間付近に多くあった許容 值を超過する部材が，主桁を連結化することによって， 主桁の変形が抑制されたためであると考えられる．中央 ヒンジ部に制震デバイスを設置した図-10と比較すると, 主桁変形の抑制効果は，制震デバイスの設置よりも主桁 の連結化が大きいことが確認された.

\section{（5）制震デバイスの併用効果}

端橋脚部と中央ヒンジ部において制震デバイスを併用 した場合の適用効果を検証するために，表-6に示すよう に, 端橋脚部には変位抑制効果に優れたせん断パネルダ ンパーを，中央ヒンジ部にはせん断パネルダンパーまた は主桁連結化を組合せたケースとした。

Case 3-1での端橋脚部および中央ヒンジ部におけるせ ん断パネルダンパーの応答履歴曲線をそれぞれ図-17お よび図-18に示す．また，Case 3-2での端橋脚部における 応答履歴曲線を図-19に示寸. 端橋脚部のせん断パネル ダンパーの応答は制震デバイスを併用しない場合とほぼ

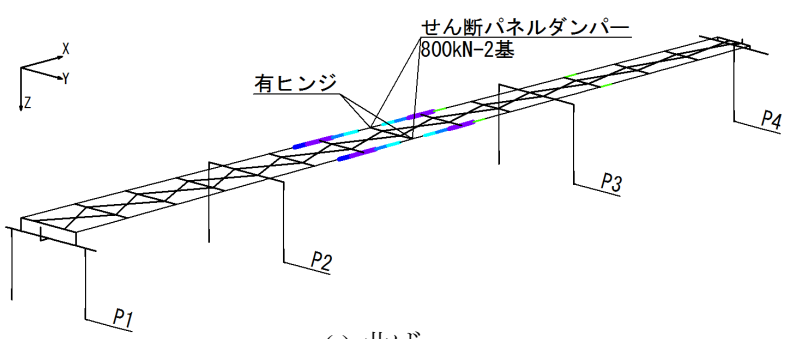

(a) 曲げ

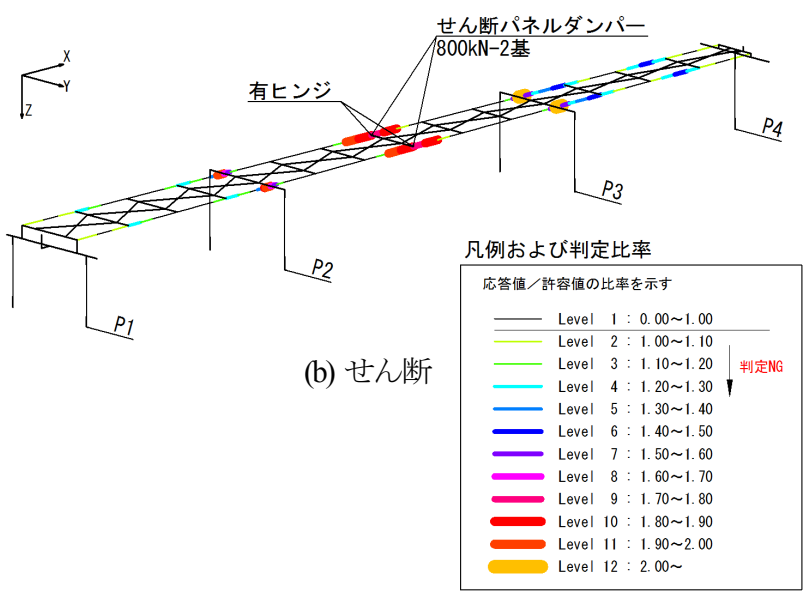

図-15 解析結果 (Case 2-1-2)
変わらないが，図-18に示寸中央ヒンジ部のせん断パネ ルダンパーの応答は図-14 (b) と比較して変位が抑制さ れていた．これは，端橋脚部へのせん断パネルダンパー 設置により，水平変位が低減するとともに，主桁の変形 が抑制されたことによると考えられる.

また，柱基部反力のせん断力の比較を表-12に示す. 端橋脚部に制震デバイスがない場合と比較すると，併用 する場合は中間橋脚P2およびP3におけるせん断力が5\% 程度低減されており，制震デバイスを併用することで橋 梁全体への分散効果があることが確認された.

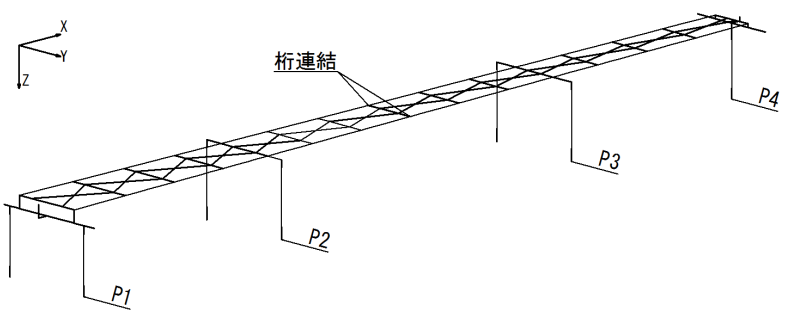

(a) 曲げ

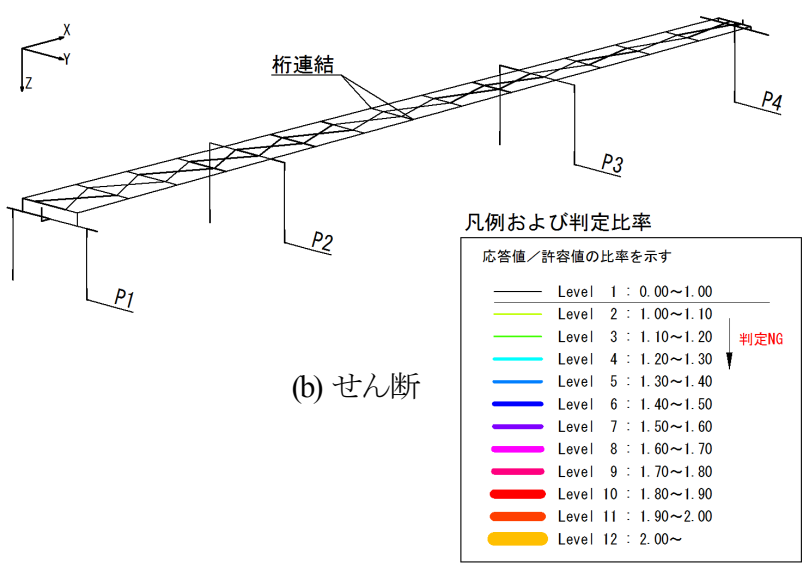

図-16 解析結果（Case2-2）

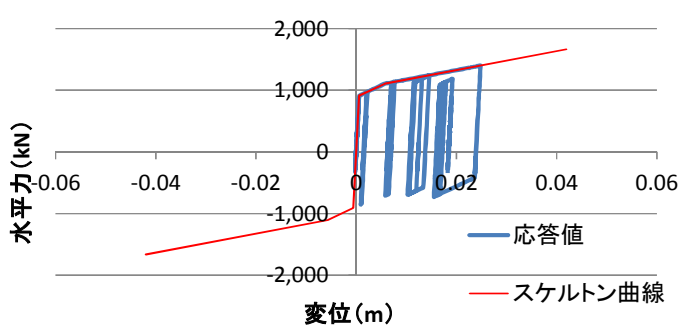

(a) P1橋脚・G1枌

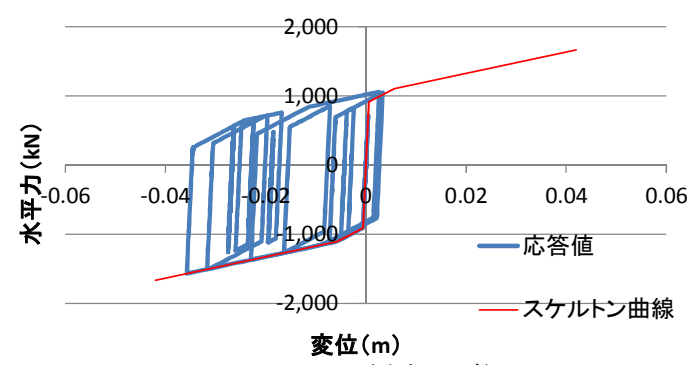

(b) P4橋脚· G1枌

図-17 端橋脚部せん断パネルダンパー履歴曲線(Case 3-1) 
Case 3-1およびCase 3-2における橋軸方向加振時の非線 形時刻歴応答解析の結果から，各部材毎に応答值を許容 值で除した比率をそれぞれ図-20および図-21に示す.

曲げに対しては，制震デバイスを併用しない場合と大 きく差はないが，せん断に対しては，橋梁全体で応答值 の低減が確認され，許容值に対する超過度が軽減してい た.これは，制震デバイスを併用することによりエネル ギ一吸収能が高められ，応答值が低減されたためと考え られる。

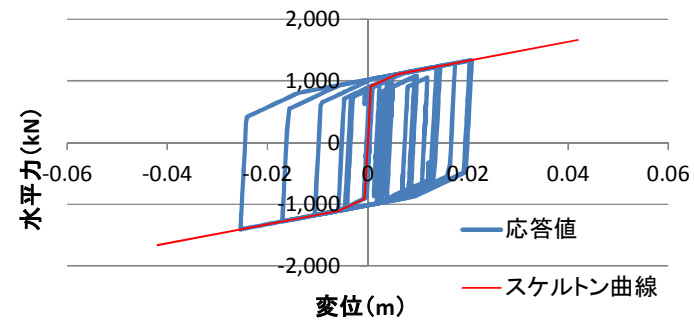

図-18 中央ヒンジ部せん断パネルダンパー履歴曲線(Case 3-1)

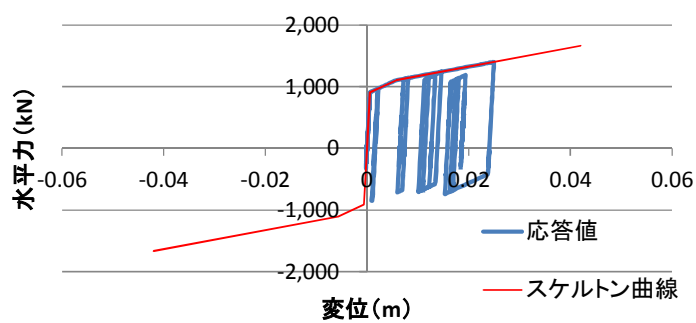

(a) $P 1$ 橋脚 $\cdot G 1$ 桁

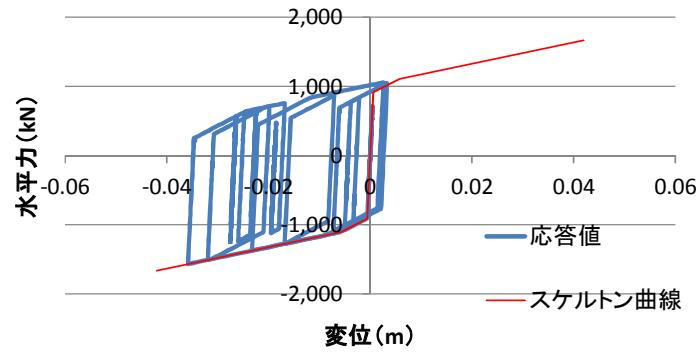

(b) P4橋脚· G1枌

図-19＼cjkstart端橋脚部せん断パネルダンパー履歴曲線(Case 3-2)

表-12 柱基部のせん断の比較

\begin{tabular}{|c|c|c|c|}
\hline \multirow{2}{*}{ 橋脚名】解析ケース } & \multicolumn{3}{|c|}{ せん断 $(\mathrm{kN})$} \\
\cline { 2 - 4 } & Case 1-2-2 & Case 2-1-2 & Case 3-1 \\
\hline P1 (左柱) & 3,058 & 2,589 & 3,067 \\
\hline P1 (右柱) & 3,081 & 2,608 & 3,092 \\
\hline P2 (左柱) & 11,631 & 12,522 & 11,895 \\
\hline P2 (右柱) & 11,630 & 12,521 & 11,893 \\
\hline P3 (左柱) & 11,827 & 12,403 & 11,894 \\
\hline P3 (右柱) & 11,817 & 12,403 & 11,894 \\
\hline P4 & 6,283 & 7,109 & 6,284 \\
\hline
\end{tabular}

なお，中央ヒンジ部を桁連結したものは制震デバイス を併用しない場合と同様に，曲げ・せん断ともに許容值 を満足する結果を得た。

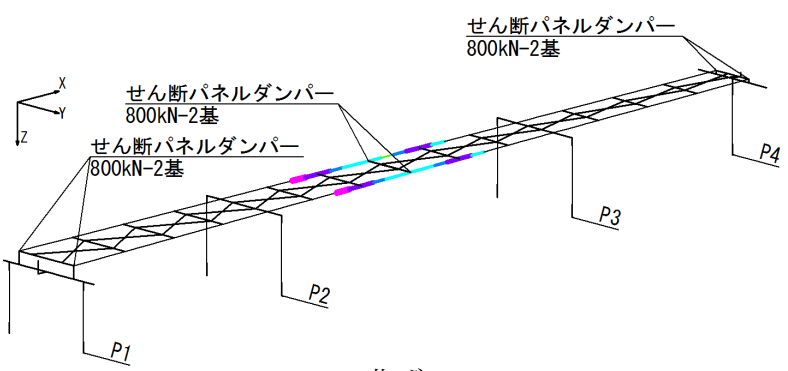

(a) 曲げ

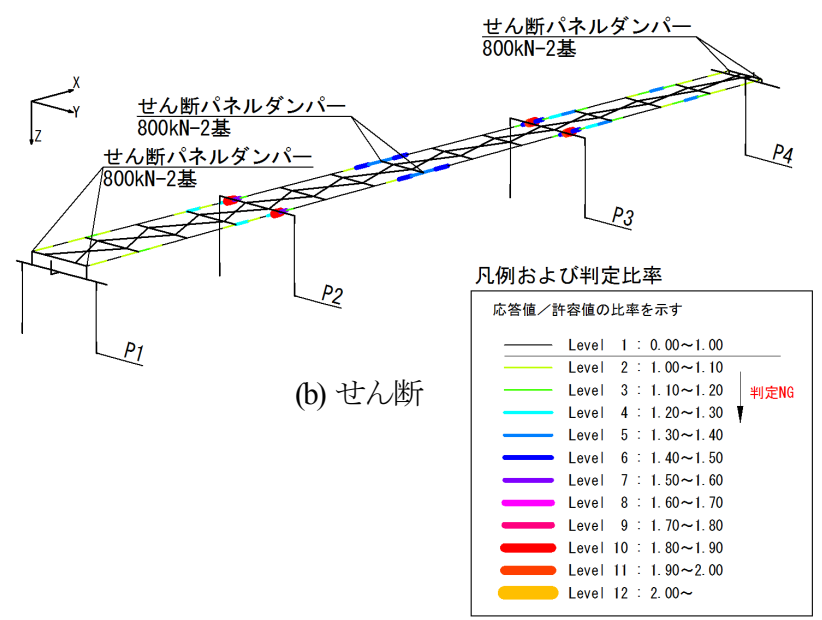

図-20 解析結果 (Case 3-1)

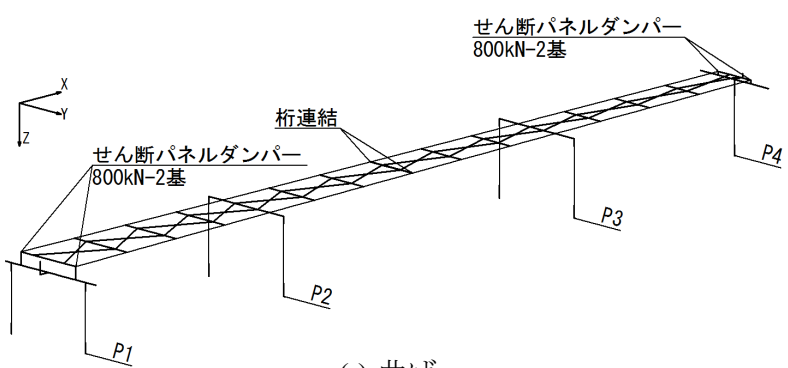

(a) 曲げ

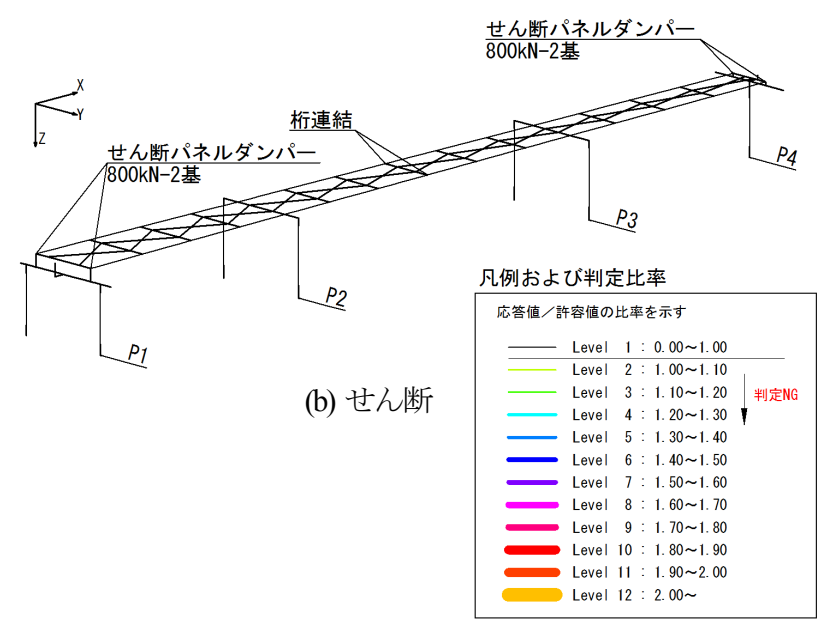

図-21 解析結果 (Case3-2) 


\section{（6）端橋脚の剛性の違いによる制震デバイスの効果}

本論文において対象とした橋梁は連続する高架区間の 一部となる橋梁である．前述した端橋脚部の制震デバイ スの効果検証から，端橋脚の剛性が比較的小さいことに よって，地震時水平力の低減効果が大きく期待できない ものと考えられる. しかしながら，山岳部では同橋種・ 同規模で橋台に挟まれた橋梁は多数存在することから， 端部橋脚を橋台と想定した場合における制震デバイスの 設置効果を検証した.

検証した解析ケースは表-13 に示すとおり，制震デバ イスを併用した Case 3-1 および Case 3-2 において，端橋 脚の剛性を橋台相当とした Case 3-1 Aおよび Case 3-2A で ある.

Case 3-1AおよびCase 3-A2における橋軸方向加振時の非 線形時刻歴応答解析の結果から, 各部材毎に応答值を許 容值で除した比率をそれぞれ図-22および図-23に示す.

Case 3-1 およびCase 3-1Aを比較すると，曲げ・せん断と もに，橋梁全体で若干の応答值低減が確認された。 これ は，端橋脚を橋台相当の岡性としたため端橋脚部の制震 デバイスのエネルギー吸収能がより一層高められ，応答 值が低減されたためであると考えられる. なお，中央七 ンジ部を桁連結したCase 3-2AはCase 3-2 と同様に, 曲 げ・せん断ともに許容值を満足する結果を得た.

端橋脚部のせん断パネルダンパーの応答履歴を図-24 に示す．橋台を想定した本ケースでは正負に变位を示し ており，効率的にエネルギ一吸収がなされていることが 確認された。

\section{（7）耐震性能向上対策案の比較}

許容值の超過が確認された現況構造に対して，而震性 能向上対策として検証した，端橋脚部におけるせん断パ ネルダンパーの設置, 中央ヒンジ部におけるせん断パネ ルダンパーの設置, 主椼連結化, さらにこれらを併用し た 5 対策案を比較した。

制震デバイスの適用による上部構造の曲げの変化につ いて，入力地震波をタイプII とした場合を図-25に示す． 負の值となる最小曲げモーメント側では，断面剛性の高 い柱頭部付近においては応答值は許容值に対して余裕が あると考えられる，一方，正の值となる最大曲げモ一メ ントにおいて，特に中央ヒンジ部付近は断面剛性が小さ いことから許容值も小さく, 現況構造断面では許容值を

表-13 而震性能解析ケース（橋台）

\begin{tabular}{|c|c|c|}
\hline \multirow{2}{*}{$\begin{array}{c}\text { 解析 } \\
\text { ケース }\end{array}$} & \multicolumn{2}{|c|}{ 而震性能向上対策 } \\
\cline { 2 - 3 } & 橋台部 & 中央ヒンジ部 \\
\hline Case3-1A & せん断パネルダンパー & せん断パネルダンパー \\
\hline Case3-2A & せん断パネルダンパー & 桁連結 \\
\hline
\end{tabular}
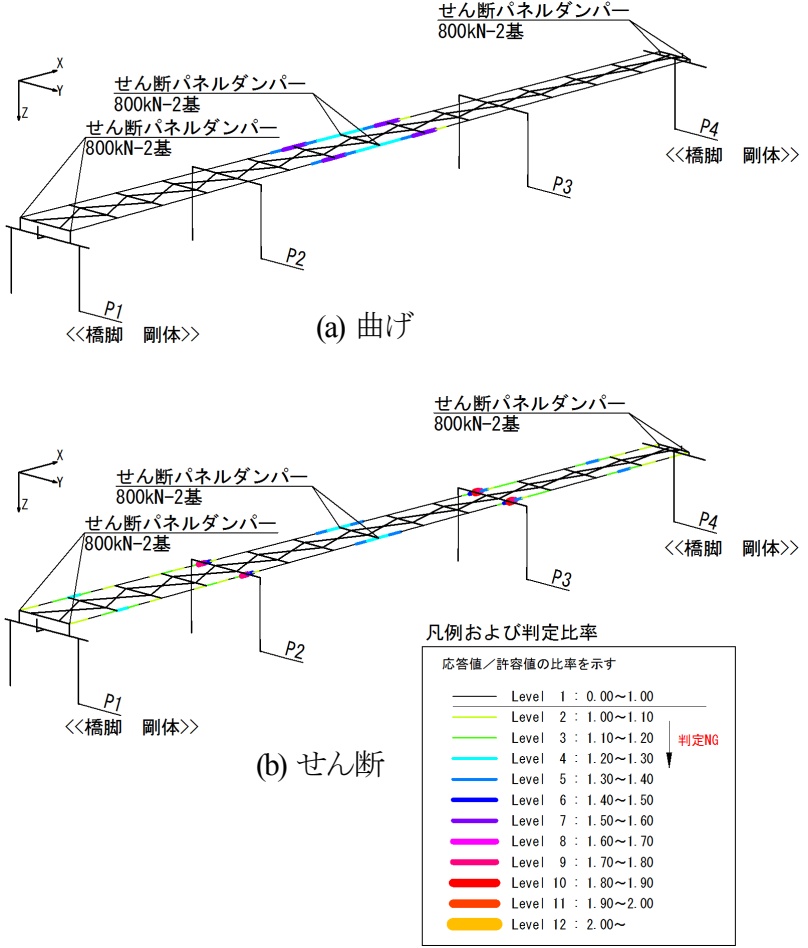

図-22 解析結果 (Case 3-1A)

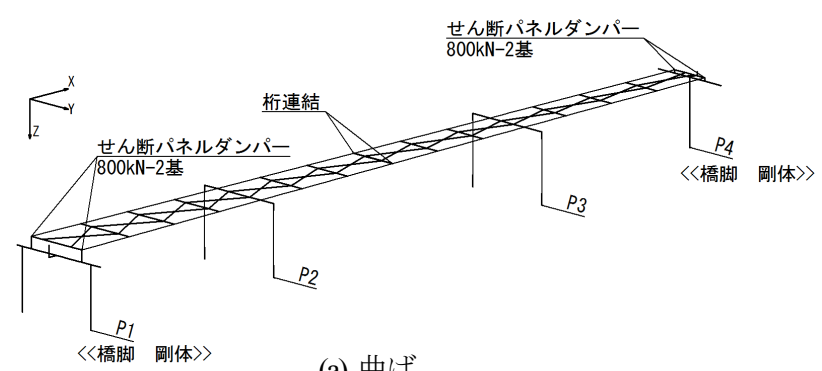

(a) 曲げ

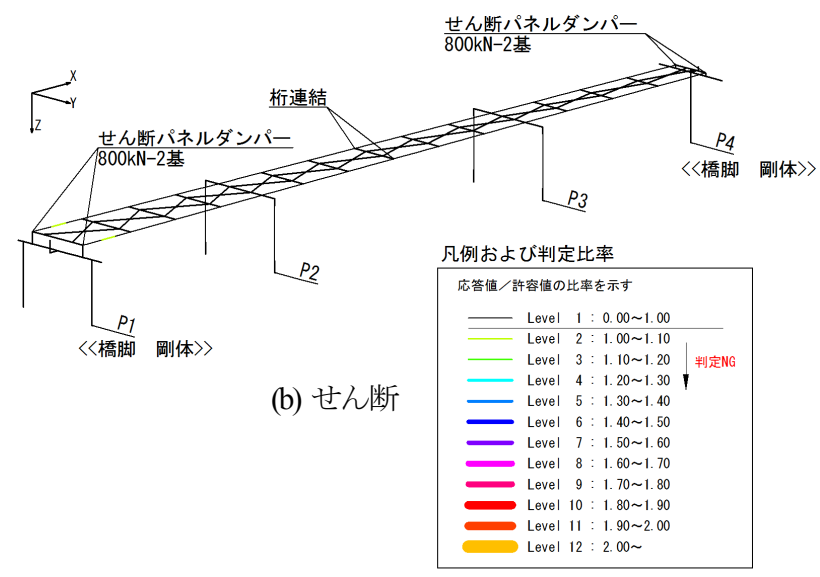

図-23 解析結果 (Case 3-2A)

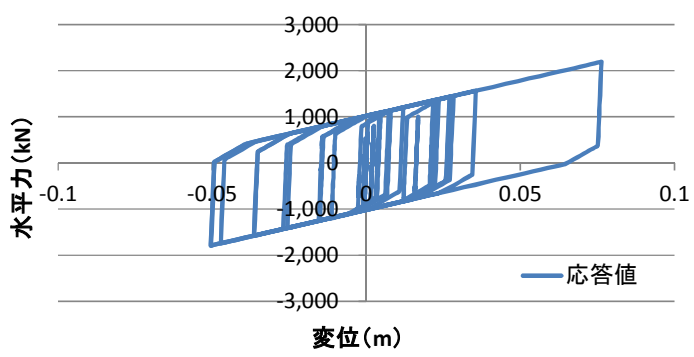

図-24端橋脚部せん断パネルダンパー履歴曲線(Case 3-1A) 
超過していた．主桁連結化による構造系変化の影響から 発生断面力は大きくなっているものの, 桁連結補強によ る許容值の増加により許容值を満足することを確認した。 なお，入力地震波をタイプ I とした場合も，タイプII と 同様の傾向を示した.

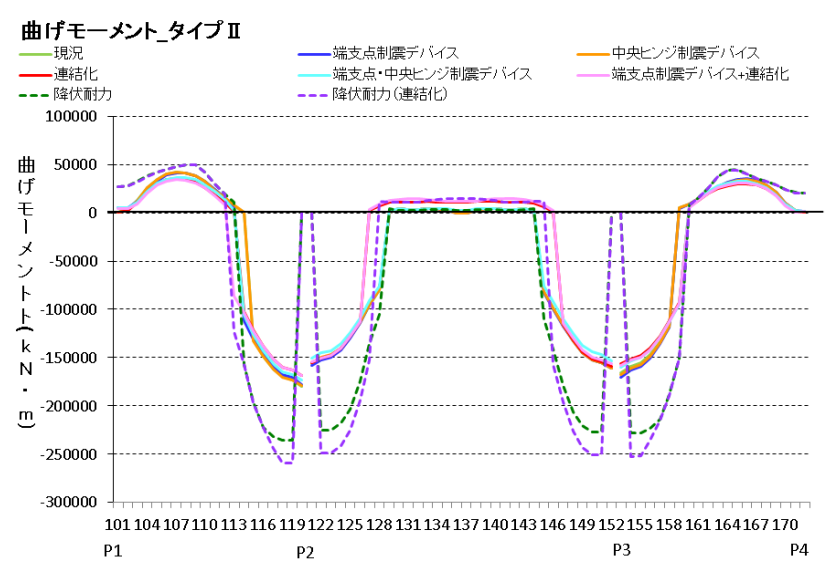

(a) 曲げ (タイプII)

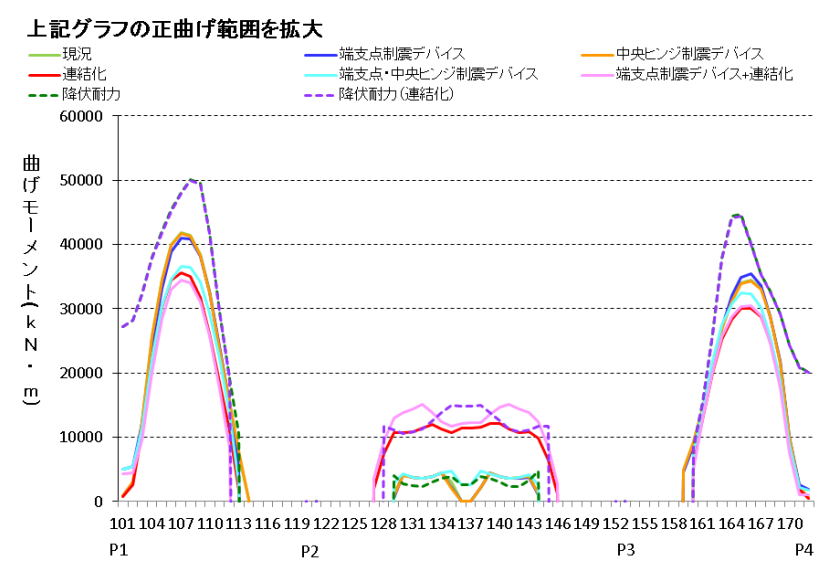

(b) 曲げ（タイプII）拡大図

図-25＼cjkstart制震デバイスの適用による上部構造の曲げの変化

表-14 端橋脚部における最大変位の比較

\begin{tabular}{|c|c|c|c|}
\hline 橋脚名 & 解析厅一ス & 最大変位量 & $(\mathrm{mm})$ \\
\hline \multirow{6}{*}{ P1 } & 現況構造 & 0.297 (3.71סa) & \\
\hline & Case 1-2 & $0.025(0.31 \delta \mathrm{a})$ & [92\%減少 $]$ \\
\hline & Case 2-1 & 0.295 (3.69סa) & \\
\hline & Case 2-2 & 0.296 (3.708a) & \\
\hline & Case 3-1 & 0.024 (0.30反a) & [92\%減少 $]$ \\
\hline & Case 3-2 & 0.025 (0.31反a) & [92\%減少 $]$ \\
\hline \multirow{6}{*}{ P4 } & 現況構造 & 0.270 (5.408a) & \\
\hline & Case 1-2 & $0.032(0.64 \delta \mathrm{a})$ & [88\%減少 $]$ \\
\hline & Case 2-1 & 0.268 (5.36סa) & \\
\hline & Case 2-2 & 0.267 (5.34סa) & \\
\hline & Case 3-1 & $0.032(0.64 \delta a)$ & [88\%減少 $]$ \\
\hline & Case 3-2 & $0.032(0.64 \delta a)$ & [88\%減少 $]$ \\
\hline
\end{tabular}

端橋脚部における水平変位について, 各解析ケースに おける比較を表-14 に示す. 前述した柱基部の応答と同 様に，端橋脚部に制震デバイスを設置した場合，端橋脚 部の変位抑制に大きく寄与することを確認した. 一方, 中央ヒンジ部に制震デバイスを設置する場合や，主桁連 結化を実施する場合は，橋梁全体系の挙動に対しては影 響がほとんどないことを確認した.

なお，端橋脚部における最大変位は，制震デバイスを 併用した Case 3-1 においても制震デバイスを併用しない Case 1-2 と大きな差はなかった. 端橋脚部の制震デバイ スが水平変位の抑制に寄与していると考えられる.

以上より，鋼橋において制震デバイスの適用による地 震応答の低減効果を得た事例 ${ }^{11)}$ と比較すると, 死荷重の 大きい PC 箱桁橋ではその効果が得られにくい傾向にあ るものの，変位抑制に関してはせん断パネルダンパーが 有効であるものと考えられる.

\section{4. まとめ}

PC有ヒンジ箱桁橋を対象に, レベル 2 地震動に対す る而震性能の評価と而震性能向上化構造の検証から得ら れた主な知見を以下にまとめる.

（1）現況構造においては，橋軸方向地震力により上部構 造全体にわたり許容值を超過し, 中央ヒンジ付近に 超過度の高い部材が集中した．鋼板巻立て補強済の 橋脚は，全て許容值内であった。

（2）端橋脚部に制震デバイスとして，粘性ダンパーまた はせん断パネルダンパーを配置した場合, エネルギ 一吸収による減衰効果が確認されたが，橋梁全体系 として曲げ・せん断の応答低減効果は軽微であった。 粘性ダンパーとせん断パネルダンパーの比較では, 曲げ・せん断の応答低減は変わらないものの, 端橋 脚部の水平変位は, 制震デバイスの設置により大き く低減し，特にせん断パネルダンパーでは約 $90 \%$ の 低減となり，変位制御の効果が高いことが確認され た.

（3）中央ヒンジ部においては，既設コンクリート構造を 鋼構造とのハイブリッド構造に改良し，制震デバイ スとしてせん断パネルダンパーを組み込んだ構造を 新たに提案した. 最適なせん断パネルダンパーの適 用により，エネルギ一吸収による減衰効果は確認さ れたが，曲げ・せん断の応答低減効果は軽微であっ た.

（4）中央ヒンジ部において, 主林を連結化した場合, 曲 げ・せん断の応答值が橋梁全体で低減し, 許容值を 超過する範囲は大きく減少した. 
（5） PC有ヒンジ箱桁橋の而震性能向上対策として，端 橋脚部と中央ヒンジ部にそれぞれせん断パネルダン パーを配置し制震デバイスを併用した場合，単独で 制震デバイスを配置した場合と比較すると, エネル ギ一吸収による減衰効果や地震時水平力の分散効果 とともに，水平変位の抑制効果はさらに大きかった． 制震デバイスの適用効果は, 死荷重の大きいコンク リート橋より死荷重の小さい鋼橋の方が高いと考え られるが，制震デバイスが設置される下部構造の断 面剛性が高い場合は，橋梁全体系の地震時挙動を抑 える効果が期待できると考えられる.

\section{参考文献}

1) 日本鋼構造協会 : 鋼橋の耐震・制震設計ガイドライン, 技報堂, 2006 .

2) 土木学会 : 鋼・合成構造標準示方書 而震設計編，丸善， 2008.

3) 土木研究センター: 道路橋の免震・制震設計法マニュア ル(案), 2011.

4) 土木学会 : 交通ネットワークを支える免震と制震の技術, 丸善, 2012.

5) Sugioka, K., Kobayashi, H. and Mashima, N.: Seismic Ret-rofit of the Cable-Stayed 640m Span Tempoan Bridge with Energy Absorbing Devices, 5th World Conference on Struc-tural Control and Monitoring, Tokyo, Japan, 2010.

6) 杉岡弘一, 濱田信彦, 小林寛, 西岡 勉, 杉山尚希 : 長大 橋用せん断パネルダンパーの弾塑性特性に関する実験的 研究，構造工学論文集,Vol.57A, pp.528-541，2011.

7) 杉岡弘一, 間嶋信博, 松下裕明, 姫野岳彦, 松村政秀: スリット型ノックオフ支承を用いた既設アーチ橋の耐震 補強，構造工学論文集，Vol.57A, pp.467-478， 2011.

8) 杉岡弘一，島 賢治，松下裕明：不整形地盤における鋼 斜張橋の耐震性能向上対策, 構造工学論文集, Vol.58A, pp.413-422, 2012.

9) 杉岡弘一, 島 賢治, 松下裕明 : 長大鋼ア一千橋の耐震 補強におけるせん断パネルダンパーの適用効果, 土木学 会論文集A1（構造・地震工学）Vol.68, No. 4, pp.I_748-I_759, 2012.

10）杉岡弘一, 藤林美早, 杉山尚希: 長大橋の耐震性能向上 策におけるせん断パネルダンパーの適用効果, 土木学会 論文集A1（構造・地震工学）Vol.69, No. 4, pp.___358-__ 365, 2013.

11) 杉岡弘一, 林 訓裕, 鈴木直人：長大鋼中路アーチ橋の 而震補強におけるせん断パネルダンパーの適用効果, 土 木学会論文集A1（構造・地震工学）Vol.70, No. 4, pp.I_654 I_663, 2014.

12）金治英貞, 浜田信彦, 石橋照久, 尼子元久, 渡邊英一： 長大橋レトロフィット用座屈拘束ブレースの構造提案と
弾塑性挙動，構造工学論文集，Vol.51A，pp. 859-870， 2005.

13）金治英貞, 鈴木直人, 香川敬生, 渡邊英一: 長大卜ラス 橋の対震性能向上化における設計入力地震動と損傷制御 構造，土木学会論文集 No.787/I-71,pp. 1-19， 2005.

14）金治英貞, 鈴木直人, 家村浩和, 高橋良和, 美濃智広, 高田佳 彦: 低摩擦型すべり支承の面圧・速度依存性検証と床組 免震構造の設計モデル構築, 土木学会論文集 $\mathrm{A}$, Vol.62, pp. 758-771, 2006.

15）五十嵐晃，井上和真，寻屋文子，家村浩和，吉田雅彦， 姫野岳彦, 長澤光弥 : 複数のゴム体を用いた積層ゴムダ ンパーの載荷試験による基本性能の検討, 土木学会地震 工学論文集, Vol.30,pp.450-455, 2009.

16) Nagasawa, M., Sumi, K., Tasaki, K. and Iemura, H.: Seismic Retrofit of the All-Free Type Cable-Stayed Higashi-Kobe Bridge with New Energy Dissipation Devices, 5th World Conference on Structural Control and Monitoring, Tokyo, Japan, 2010.

17) 阪神高速道路株式会社技術部：長大橋における免震・制 震デバイスの適用ガイドライン(案), 2009.

18）野中哲也, 宇佐美勉, 吉野広一, 坂本佳子, 鳥越卓志: 上路式鋼アーチ橋の大地震時弹塑性挙動及び而震性向上 に関する研究，土木学会論文集，No.731/I-63,pp.31-49, 2003.

19）小池洋平, 谷中聡久, 尾下里治, 春日井俊博: せ九断パ ネル型ダンパーを用いた鋼上路アーチ橋の耐震性向上に 関寸る解析的研究，構造工学論文集，Vol.54A，pp.382-393， 2008.

20) 陳 渓, 葛 漢彬 : せん断パネルダンパーによる鋼アーチ 橋の耐震性向上及びせん断パネルダンパーの要求性能に 関する研究，構造工学論文集，Vol.57A，pp.514-517，2011.

21）岡野素之, 松本信之, 兽我部正道, 室野剛隆, 大内一, 大野了: 振動台実験による鋼製ダンパー・ブレース付き 高架橋の地震応答性状, 構造工学論文集, Vol.49A, pp.963-970, 2003.

22）山本俊夫, 瀬戸口嘉明, 堂園和馬, 安永正道 : 京橋橋の 補修工事について，プレストレストコンクリート，Vol.31， No.6, p.31-39, 1989.

23）鈴木 威, 若槻晃右, 真鍋英規, 西 弘: 喜連瓜破高架 橋の補強設計および施工一下弦ケーブルを用いた有ヒン ジラーメン橋のたわみ回復補強, プレストレストコンク リート, Vol.46,No.5, pp.45-54, 2004.

24) 伊東浩司, 富田靖二, 尾原文宏, 滝憤一郎： PC箱析橋の 中央ヒンジの連結化一本谷川第三橋, プレストレストコ ンクリート, Vol.47,No.2, pp.59-66, 2005.

25) H. Nishi, H. Manabe, T. Suzuki, and K. Sugioka: Countermeasure against Subsidence in Cetral Hinge on PC Bridge Using External Cables, Proc. of 2nd fib Congress, Naples, Italy, 2006.

26) 渡辺将之, 上杉泰右, 東田 学: P C 3 径間連続有ヒンジ箱 桁橋の連続化について（東北自動車道八幡平橋）, コン 
クリート工学年次論文集, Vol.31, No.2, pp.1501-1506, 2009.

27) 杣辰雄, 勝谷康之, 田中秀一 : PC有ヒンジラーメン橋の 動的振動特性および而震補強検討, 土木学会第65回年次 学術講演会, pp.137-138, 2010.

28）日本道路協会 : 道路橋示方書・同解説 $V$ 耐震設計編，丸 善, 2012.
29) 日本道路協会 : 道路橋示方書 - 同解説 $V$ 而震設計編, 丸 善, 2002.

30）日本道路協会 : 道路橋の耐震設計に関する資料一PCラー メン橋・RCアーチ橋・PC斜張橋・地中連続壁基礎・深礎 基礎等の而震設計計算例一, 丸善, 1998 .

SEISMIC PERFORMANCE EVALUATION OF A PC HINGED RIGID FRAME BRIDGE BY APPLYING SEISMIC RESPONSE CONTROL DEVICES AND CONTINUING BEAMS

\author{
Koichi SUGIOKA, Takahisa FUKUSHIMA and Nobuhiro MITSUKAWA
}

Seismic retrofit design of a PC hinged rigid-frame bridge against Level 2 earthquake ground motions was performed by using seismic response control devices at piers and the central hinge, and continuing main girders at the central hinge section. Three-dimensional non-linear dynamic time history analyses were carried out using earthquake ground motions specified in the current specifications for highway bridges, in order to improve seismic performance of the bridge. Dynamic performances were compared by changing the type and arrangement of the seismic response control devices. For installing seismic response control devices at piers or the central hinge, effects on seismic response reduction were confirmed, compared with the as-built bridge. For installing shear panel dampers both at piers and the central hinge, more effects on seismic response reduction were confirmed. It was also found that continuing main girders at the central hinge section and installing shear panel dampers at piers was effective with retrofit areas and retrofit members getting smaller. 